\title{
Development of a Novel Solid-State Sensor Electrode Based on Titanium Thin Film as an Indicator Electrode in Potentiometric and Conductometric Acid-Base Titration in Aqueous Solution
}

\author{
Nasser Abu Ghalwa \\ Chemistry Department, Al Azhar University, Gaza, Palestine \\ Correspondence should be addressed to Nasser Abu Ghalwa, dr.nasser.galwa@hotmail.com
}

Received 28 May 2012; Revised 2 October 2012; Accepted 7 October 2012

Academic Editor: Jiri Homola

Copyright (C) 2012 Nasser Abu Ghalwa. This is an open access article distributed under the Creative Commons Attribution License, which permits unrestricted use, distribution, and reproduction in any medium, provided the original work is properly cited.

\begin{abstract}
A modified $\mathrm{Ti} /\left(\mathrm{SnO}_{2}+\mathrm{Sb}_{2} \mathrm{O}_{3}\right)$ electrode was prepared by thermal deposition on titanium substrate and its use as indicator electrode to potentiometric and conductometric acid-base titration in aqueous solution at $298 \mathrm{~K}$ was developed. The E-pH curve is linear with slope of $0.0512 \mathrm{~V} / \mathrm{dec}$ at $298 \mathrm{~K}$. The standard potential of this electrode, $E^{0}$, was determined with respect to the SCE as reference electrode. The recovery percentages for potentiometric and conductometric acid-base titration for acetic acid against $\mathrm{NaOH}$ were calculated. The cell constant, specific conductance, and the molar conductance with dilution for some common electrolytes were measured.
\end{abstract}

\section{Introduction}

Proton sensitive metal oxides seem to be promising alternatives to the state-of-the-art measuring methods and might overcome some problems of classical hydrogen electrodes and reference electrodes [1].

Metal oxide electrodes are becoming alternatives to glass electrodes. They, can be used as acid-base indicator electrodes. However in extreme acidic and basic conditions of the $\mathrm{pH}$ scale, great deviations of the Nernstian behavior are observed [2]. Recently, many potentiometric methods developed for measuring the acidity and basicity for aqueous solutions under different conditions were reported [3]. Different metal/metal oxide electrodes have been used as acid-base indicator electrodes. Of those, the most frequently used are the antimony, niobium, copper, tantalum, stainless steel, iridium, and tungsten electrodes [4-6].

The glass electrode is by far the most commonly used $\mathrm{pH}$ sensor due to its sensitivity, selectivity, stability, and long lifetime [7]. However, it has several disadvantages due to the intrinsic nature of the glass membrane. One is the glass bulb is mechanical not so stable and it breaks very easily so that such electrodes cannot be used for food application. Another drawback is that glass electrodes cannot be designed in planar structures. The drawbacks of glass electrodes have led to intensive research for alternative $\mathrm{pH}$ electrodes. As a result, various kinds of potentiometric $\mathrm{pH}$ sensors have been developed [8-13].

Titanium/titanium-oxide electrode has been prepared and used as indicator electrode in potentiometric acid-base and oxidation-reduction titration in aqueous solution. The $E$-pH curve is linear with slope closed to the theoretical value $2.303 \mathrm{RT} / \mathrm{F}(0.059 \mathrm{~V}$ at $298 \mathrm{~K})$. This electrode has been tested for potentiometric titration of acetic, propanoic, and phosphoric acids against $\mathrm{NaOH}$ in aqueous medium at $298 \mathrm{~K}$ [14].

$\mathrm{Ti} / \mathrm{PbO}_{2} / \mathrm{SnO}_{2}$ electrode was prepared by thermal deposition of $\mathrm{Sn}$ on titanium substrate and its use as indicator electrode in potentiometric titration in aqueous solution at $298 \mathrm{~K}$ was studied. The $E-\mathrm{pH}$ curve is linear with slope of $0.0501 \mathrm{~V} / \mathrm{dec}$ at $298 \mathrm{~K}$. The standard potential of this electrode, $E^{0}$, is computed as $722.9 \mathrm{mV}$ with respect to saturated calomel electrode as reference electrode [15].

Conductometric titrations have a more selective character when acid-base, complexometric or precipitation reactions are explored [16-18], thus widening the range of analytical applications. Pantel and Weisz had developed conductometric and high-frequency conductometric methods 
for the determination of endpoint of catalytic titrations [19]. A simultaneous conductometric titration method for determination of mixtures of acetic acid, monochloroacetic acid, and trichloroacetic acid based on the multivariate calibration partial least squares was proposed by Ghorbani et al. [20]. Fifteen metal acetates in aqueous medium have been conductometrically titrated with trichloroacetic acid by Gaslini and Nahum [21]. Wu et al. fabricated miniaturized polysilicon electrodes for conductometric sensors and compared them to Pt black and Pt electrode. This conductometric setup was used to detect urea concentration [22]. A new design of a dual, UV photometric-contactless conductometric detector was described by Novotny et al. [23].

A conductometric biosensor for nitrite detection was developed and reported by Zhang et al. [24]. A conductometric biosensor for phosphate [25] and ammonium detection [26] was developed based on interdigitated conductometric thin-film planar electrodes.

A careful review of the literature spotted no mention of an indicator electrode in potentiometric and conductometric acid-base titration in aqueous solution and made the intent to explore the development of a novel solid-state sensor electrode based on titanium thin film as an indicator electrode for potentiometric and conductometric acid-base titration in aqueous solution.

In the present study the modified electrode, $\mathrm{Ti} /\left(\mathrm{SnO}_{2}+\right.$ $\mathrm{Sb}_{2} \mathrm{O}_{3}$ ), is prepared and used for the first time as an indicator electrode against standard calomel electrode for potentiometric titration. A pair of the above-modified electrode is used for conductometric acid-base and oxidation-reduction titrations in aqueous solutions.

\section{Experimental}

\subsection{Preparation of Electrodes: $\mathrm{Ti} /\left(\mathrm{SnO}_{2}+\mathrm{Sb}_{2} \mathrm{O}_{3}\right)$}

2.1.1. Treatment of Titanium Surface. The pretreatment of titanium surface was carried out according to the procedures suggested by Yang et al. [27] as follows: a titanium sheet was polished on 320-grit paper strips, using water as lubricant, followed by $1 \mu \mathrm{m}$ siliceous past blasting. The sheet was then degreased in $40 \% \mathrm{NaOH}$, cleaned in a hot 1:1 mixture of $\mathrm{HNO}_{3}$ and $\mathrm{H}_{2} \mathrm{SO}_{4}$, and finally washed with water. The treated surface was immersed in a boiling aqueous solution of oxalic acid, $15 \%$ until the $\mathrm{TiO}_{2}$ dissolved. Coating by active metal oxide was carried out immediately to minimize formation of $\mathrm{TiO}_{2}[28]$.

2.1.2. Coating of Mixture of $\mathrm{SnO}_{2}$ and $\mathrm{Sb}_{2} \mathrm{O}_{3}$ on Ti/Surface. The thermal deposition of $\mathrm{SnO}_{2}$ on titanium sheet was carried out according to the procedure of Lipp and Pletcher [29] as follows: the pretreated titanium sheet was immersed for a few minutes in a solution of $\mathrm{SnCl}_{4} \cdot 5 \mathrm{H}_{2} \mathrm{O}, 20 \% \mathrm{wt}$ and $\mathrm{SbCl}_{3}, 2 \% \mathrm{wt}$ in 2-propanol. The excess of alcohol was allowed to evaporate by heating in air at $90^{\circ} \mathrm{C}$ for $10 \mathrm{~min}$. This stage was then repeated. After two applications, the oxide layer was formed thermally by heating at $500^{\circ} \mathrm{C}$ for
$20 \mathrm{~min}$ in a muffle furnace, with a low and continuous flow of oxygen. These stages were repeated until the $\mathrm{SnO}_{2}$ coating reached a loading of $0.8( \pm 0.01) \mathrm{mg} \mathrm{cm}^{-2}$. It was normal to employ five applications. Finally, the coating was annealed at $500^{\circ} \mathrm{C}$ for 60 minutes [28].

2.2. Chemicals. The chemicals used in potentiometric titrations and preparation the electrode were, $\mathrm{CH}_{3} \mathrm{COOH}$, ferrous ammonium sulphate, $\mathrm{NaOH}, \mathrm{KMnO}_{4}, \mathrm{HNO}_{3}, \mathrm{H}_{2} \mathrm{SO}_{4}$, $\mathrm{NaF}$, 2-propanol, $\mathrm{SnCl}_{4} \cdot 5 \mathrm{H}_{2} \mathrm{O}, \mathrm{SbCl}_{3}$, and oxalic acid. The chemicals are of analytical pure grade.

\subsection{Sensor Design of Potentiometric Cell}

2.3.1. Developed Electrode. The $\mathrm{Ti} /\left(\mathrm{SnO}_{2}+\mathrm{Sb}_{2} \mathrm{O}_{3}\right)$ electrode was $(20 \mathrm{~cm} \times 1 \mathrm{~cm})$ and about $2 \mathrm{~mm}$ thick. It was coupled with a saturated calomel electrode (SCE) to complete the electrical circuit and measure the potential difference between these two electrodes using a digital multimeter model 1008 (Kyoritsu, Japan). Potentials were measured with an accuracy of $\pm 5 \mathrm{mV}$. The error in the measurement of the potential, due to liquid-junction potentials in these electrolytes, is estimated to be about $0.005 \mathrm{~V}$ [30].

2.3.2. Electrode Calibration in Potentiometric. $\mathrm{Ti} /\left(\mathrm{SnO}_{2}+\right.$ $\mathrm{Sb}_{2} \mathrm{O}_{3}$ ) electrode was calibrated by immersing the electrode and a reference electrode in a solution of known $\mathrm{pH}$ at constant temperature $\left(25^{\circ} \mathrm{C}\right)$ and applying to them a setting potential which is approximately equal to the steady-state potential that would be observed for that electrode with respect to the reference electrode in a solution of that value of $\mathrm{pH}$.

2.3.3. Experimental Setup. Titration was carried out in a Pyrex glass beaker using $50 \mathrm{~mL}$ of the reductant and the base or the oxidant placed in a microburette. The solution in a beaker is stirred by means of a magnetic stirrer. The electrodes (indicator and reference) were dipped slowly into the aqueous solution (acid or reductant). After the steadystate potential was attained, the titration of the acid was carried out by addition of $1 \mathrm{~mL}$ of the base to the acidic solution, waiting until the steady potential is established and then measured. The potential variation depends on the type of the base, the progress of neutralization process, and on the initial concentration of the acid to be titrated. The results were reproducible and satisfactory with an accuracy of $\pm 5 \mathrm{mV}$ for potential measurements. The process of addition of the titrant was continued until the equivalence point was reached.

\subsection{Sensor Design of Conductometric Cell}

2.4.1. Developed Conductometric Cell. Conductometric cells consist of two identical pairs of $\mathrm{Ti} /\left(\mathrm{SnO}_{2}+\mathrm{Sb}_{2} \mathrm{O}_{3}\right)$ electrodes $1 \mathrm{~cm}$ apart. Each electrode was with dimensions $(1 \mathrm{~cm} \times$ $1 \mathrm{~cm}$ ) and with about $2 \mathrm{~mm}$ thickness. They were coupled with each other to complete the electrical circuit and the conductometric sensors were used to measure the resistance 


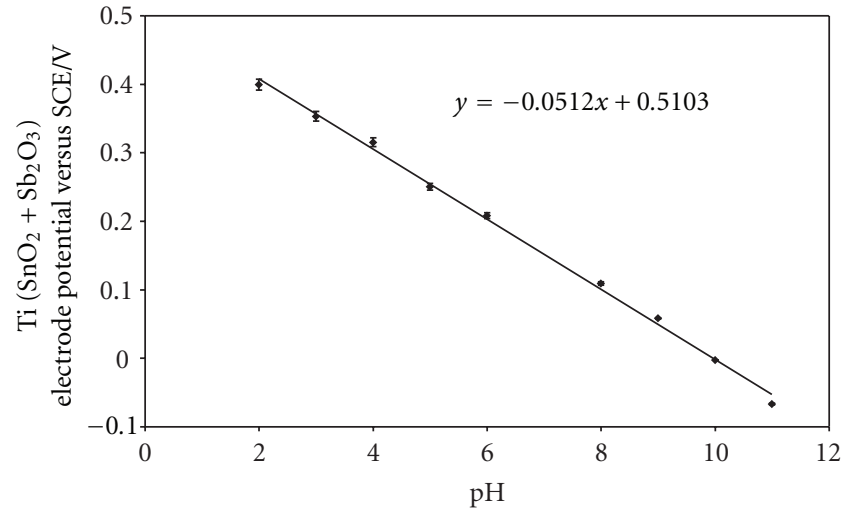

Figure 1: E-pH relation for $\mathrm{Ti} /\left(\mathrm{SnO}_{2}+\mathrm{Sb}_{2} \mathrm{O}_{3}\right)$ electrode at $298 \mathrm{~K}$.

(in ohms) or conductance (the reciprocal of resistance) between these two electrodes.

2.4.2. Conductometric Cell Calibration. Calibration of conductivity cell is usually made by using a conductivity simulator (CM-30 V) (TOA Electronic Ltd., 44CT, 121w, Japan). After calibrating the instrument by simulator, connect the sensor and cross check by using standard solutions for single point as per process range.

2.4.3. Experimental Setup. Titration was carried out in a pyrex glass beaker using $100 \mathrm{~mL}$ of the acid and the base placed in a microburette. The solution in a beaker is stirred by means of a magnetic stirrer. The cell was dipped slowly into the aqueous solution. After the steady-state potential was attained, the measuring results obtained.

\section{Results and Discussion}

3.1. The Use of $\mathrm{Ti} /\left(\mathrm{SnO}_{2}+\mathrm{Sb}_{2} \mathrm{O}_{3}\right)$ Electrode as an Indicator Electrode in Potentiometric Acid-Base Titration in Aqueous Solution at $298 \mathrm{~K}$

3.1.1. The E-pH Relation of $\mathrm{Ti} /\left(\mathrm{SnO}_{2}+\mathrm{Sb}_{2} \mathrm{O}_{3}\right)$ Electrode. Figure 1 shows the change of the open circuit potential, $E$, of the $\mathrm{Ti} /\left(\mathrm{SnO}_{2}+\mathrm{Sb}_{2} \mathrm{O}_{3}\right)$ electrode with $\mathrm{pH}$. The $E$-pH plot of the $\mathrm{Ti} /\left(\mathrm{SnO}_{2}+\mathrm{Sb}_{2} \mathrm{O}_{3}\right)$ electrode fits straight line with slope of $0.0512 \mathrm{~V} /$ decade at $298 \mathrm{~K}$.

This value is close to the magnitude of the term $2.303 \mathrm{RT} / \mathrm{F}$ at the corresponding temperature $(0.059 \mathrm{~V}$ at $298 \mathrm{~K}$ ) which indicates that the working electrode behaves reversibly and can be used as an indicator electrode for $\left[\mathrm{H}^{+}\right]$ determination:

$$
\mathrm{Sn}+2 \mathrm{Sb}+5 \mathrm{H}_{2} \mathrm{O} \longrightarrow \mathrm{SnO}_{2}+\mathrm{Sb}_{2} \mathrm{O}_{3}+10 \mathrm{H}^{+}+10 \mathrm{e}^{-} \text {. }
$$

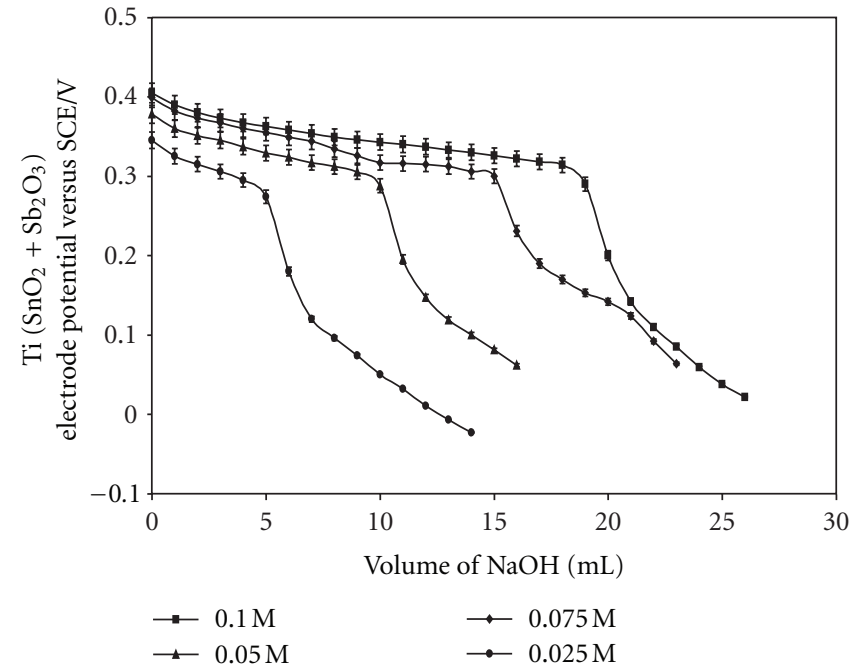

FIgURE 2: Potentiometric titration of acetic acid with $0.1 \mathrm{M} \mathrm{NaOH}$ at $298 \mathrm{~K}$.

Nernst equation of this reaction can be written as

$$
\begin{aligned}
& E_{\mathrm{Ti} / \mathrm{SnO}_{2}+\mathrm{Sb}_{2} \mathrm{O}_{3}} \\
& \quad=E_{\mathrm{Ti} /\left(\mathrm{SnO}_{2}+\mathrm{Sb}_{2} \mathrm{O}_{3}\right)}^{0}+\frac{2.303 R T}{10 F} \log \frac{\left[\mathrm{SnO}_{2}+\mathrm{Sb}_{2} \mathrm{O}_{3}\right]\left[\mathrm{H}^{+}\right]^{10}}{[\mathrm{Sn}+2 \mathrm{Sb}]\left[\mathrm{H}_{2} \mathrm{O}^{+}\right]^{5}},
\end{aligned}
$$

where the activity coefficient for dilute solution equals unit and $(\mathrm{Sn}+\mathrm{Sb})$ and $\left(\mathrm{SnO}_{2}+\mathrm{Sb}_{2} \mathrm{O}_{3}\right)$ are solids. $\mathrm{H}_{2} \mathrm{O}$ in excess, their activities equal unit also

$$
E_{\mathrm{Ti} /\left(\mathrm{SnO}_{2}+\mathrm{Sb}_{2} \mathrm{O}_{3}\right)}=E_{\mathrm{Ti} /\left(\mathrm{SnO}_{2}+\mathrm{Sb}_{2} \mathrm{O}_{3}\right)}^{0}-\frac{2.303 R T}{F} \mathrm{pH} .
$$

This equation is applicable for the reversible behavior of working electrode. From the developed Nernst equation we indicate that working electrodes can be used as $\mathrm{pH}$-indicator. From Figure 1 the $E^{0}$ value of the $\mathrm{Ti} /\left(\mathrm{SnO}_{2}+\mathrm{Sb}_{2} \mathrm{O}_{3}\right)$ electrode, that is, the potential at $\left[\mathrm{H}^{+}\right]=1$, is computed as $510 \mathrm{mV}$ relative to the saturated calomel electrode.

At high or low $\mathrm{pH}$, the electrode indicates $\mathrm{pH}$ less than true value as $\mathrm{pH}$ glass electrode, it may be due to damage in electrode or existence of alkali metal ions in solution too.

3.1.2. Potentiometric Acid-Base Titration. Figure 2 represents the relation between the volume of $0.1 \mathrm{MNaOH}$ with each potential shift in the titrations of acetic acid. The variation of the $\mathrm{Ti} /\left(\mathrm{SnO}_{2}+\mathrm{Sb}_{2} \mathrm{O}_{3}\right)$ electrode potential at $298 \mathrm{~K}$ with the different volumes of $\mathrm{NaOH}$ followed typical potentiometric titration curves. These curves show slight decrease in potential (to more negative values) with the addition of the titrant.

For locating endpoints, better results are obtained by constructing a plot of $\Delta E / \Delta V$ against $V$ of titrant. Figure 3 represents $\Delta E / \Delta V$ against $V$ for the potentiometric titrations of $\mathrm{CH}_{3} \mathrm{COOH}$ against $0.1 \mathrm{M} \mathrm{NaOH}$. From the plots the values of endpoints are determined. The obtained results are listed in Table 1 for acetic acid. 


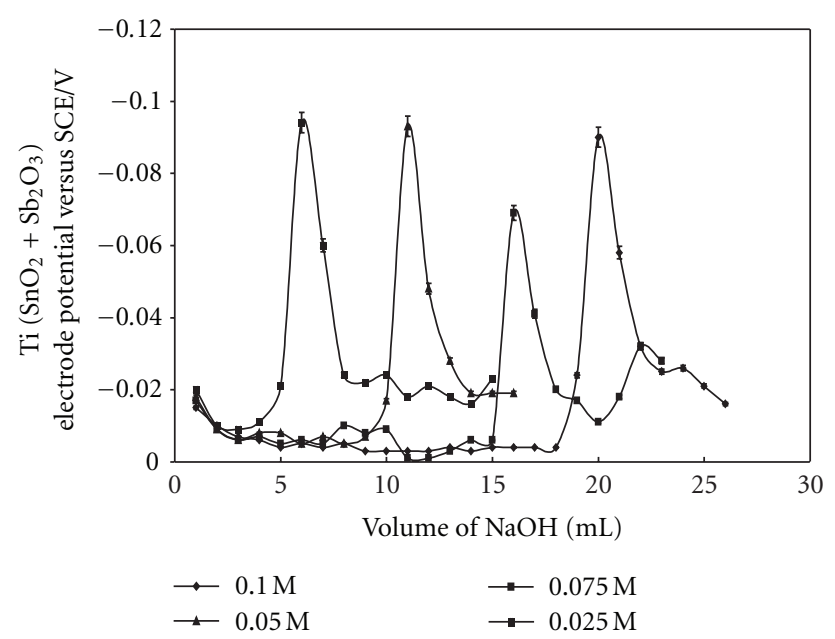

FIGURE 3: Locating the endpoints for potentiometric titration of acetic acid with $0.1 \mathrm{M} \mathrm{NaOH}$ at $298 \mathrm{~K}$.

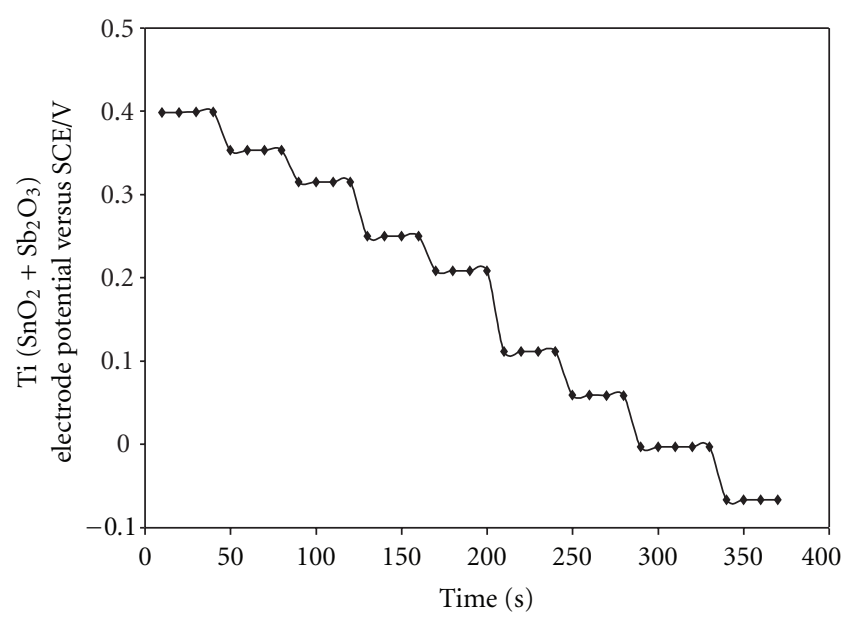

FIgURE 4: Time response curve of $\mathrm{Ti} /\left(\mathrm{SnO}_{2}+\mathrm{Sb}_{2} \mathrm{O}_{3}\right)$ electrode potential at different $\mathrm{pH}$ values. Upper curve at $\mathrm{pH}=2$ and lower for $\mathrm{pH}=11$.

The values of the recovery percentage, $R \%$, for all above titrations are calculated from (4). From the plots the values of endpoints and the values of the recovery percentage, $R \%$, are determined as

$$
R \%=\frac{B_{e}}{B_{t}} \times 100 \%
$$

where $B_{e}$ is the experimental amount of base and $B_{t}$ is the theoretical amount of base calculated from the soichiometric equations of neutralization reactions. It is clear from these data that the working electrode can be used as indicator electrode with the satisfactory percentage recovery not less than $96.1 \%$ in potentiometric titrations. These differences in the recovery percentage may be attributed to the impurities in the reagents. The values of $\mathrm{pK}_{\mathrm{a}}$ for different acids can be determined using the method of half neutralization [31]. They are close to the previously reported values listed in Table 2 for the tested acids.
TABLE 1: The molar amounts $\mathrm{A}$ of $\mathrm{CH}_{3} \mathrm{COOH}$ acid, experimental and theoretical amounts of $\mathrm{NaOH}, B_{e}, B_{t}$, and recovery percentage $(R \%)$ for acid-base potentiometric titrations using $\mathrm{Ti} /\left(\mathrm{SnO}_{2}+\right.$ $\mathrm{Sb}_{2} \mathrm{O}_{3}$ ) indicator electrode.

\begin{tabular}{lccc}
\hline $\mathrm{A}(\mathrm{M})$ & $B_{e}(\mathrm{M}) \mathrm{NaOH}$ & $B_{t}(\mathrm{M}) \mathrm{NaOH}$ & $R \%$ \\
\hline 0.1000 & 0.100 & 0.1000 & 100.00 \\
0.0750 & 0.082 & 0.0750 & 109.30 \\
0.0500 & 0.045 & 0.0500 & 90.24 \\
0.0250 & 0.027 & 0.0250 & 108.00 \\
\hline
\end{tabular}

TABLE 2: The molar amounts $\mathrm{A}$ of $\mathrm{CH}_{3} \mathrm{COOH}$ acid and experimental $\mathrm{pK}_{\mathrm{a}}$ for acid-base titrations using $\mathrm{Ti} /\left(\mathrm{SnO}_{2}+\mathrm{Sb}_{2} \mathrm{O}_{3}\right)$ indicator electrode.

\begin{tabular}{ll}
\hline $\mathrm{A}(\mathrm{M})$ & $\mathrm{pK}_{\mathrm{a}}$ \\
\hline 0.100 & 4.75 \\
0.075 & 4.73 \\
0.050 & 4.75 \\
0.025 & 4.76 \\
\hline
\end{tabular}

TABLE 3: The molar amounts $\mathrm{A}$ of $\mathrm{CH}_{3} \mathrm{COOH}$ acid, experimental and theoretical amounts of $\mathrm{NaOH}, B_{e}, B_{t}$ and recovery percentage $(R \%)$ for acid-base conductometric titrations using $\mathrm{Ti} /\left(\mathrm{SnO}_{2}+\right.$ $\mathrm{Sb}_{2} \mathrm{O}_{3}$ ) as indicator electrode.

\begin{tabular}{lccc}
\hline $\mathrm{A}(\mathrm{M})$ & $B_{e}(\mathrm{M}) \mathrm{NaOH}$ & $B_{t}(\mathrm{M}) \mathrm{NaOH}$ & $R \%$ \\
\hline 0.100 & 0.1000 & 0.100 & 100.0 \\
0.075 & 0.0738 & 0.075 & 98.5 \\
0.050 & 0.0480 & 0.050 & 96.1 \\
0.025 & 0.0255 & 0.025 & 102.3 \\
\hline
\end{tabular}

3.1.3. The Response Time of the Sensor. Figure 4 shows the time response curve as the continuous dependence of the potential on time for several step changes of $\mathrm{pH}$. Response time of the $\mathrm{Ti} /\left(\mathrm{SnO}_{2}+\mathrm{Sb}_{2} \mathrm{O}_{3}\right) \mathrm{pH}$ sensor, in the range of (50-70) seconds, was achieved, which rendered the sensor highly practical.

3.1.4. Effect of Temperature on the Response Characteristics. The $\mathrm{Ti} /\left(\mathrm{SnO}_{2}+\mathrm{Sb}_{2} \mathrm{O}_{3}\right) \mathrm{pH}$ sensor response was evaluated at different temperature, Figure 5. At lower temperatures like $283 \mathrm{~K}$, the slope of the sensor was about $43.7 \mathrm{mV} /$ decade and the sensor would be used for $\mathrm{pH}$ measurements in the range from 2 to 11 . However, when the temperature of test solutions was adjusted to $333 \mathrm{~K}$, the slope significantly increased to $56.8 \mathrm{mV} /$ decade and the slope reached the value of $60.4 \mathrm{mV} /$ decade at $353 \mathrm{~K}$.

Figure 6 shows the square of the correlation coefficient $\left(r^{2}\right)$ for $\mathrm{pH}$ measurements using the solid-state sensor at different temperatures as compared to $\mathrm{pH}$ values obtained by a conventional $\mathrm{pH}$ electrode (Hanna Instruments HI 1131 $\mathrm{pH}$ combination electrode). It was found to increase as the temperature increases, whereas $r^{2}$ values for measurements at $283 \mathrm{~K}, 298 \mathrm{~K}, 333 \mathrm{~K}$, and $353 \mathrm{~K}$ were $0.9964,0.9974,0.9983$, and 0.9994, respectively. This indicates that better results could be obtained at higher temperature. Overall, it can be easily recognized that there is an excellent correlation 
TABLE 4: The endpoints of different concentrations of $\mathrm{CH}_{3} \mathrm{COOH}$ acid for $\mathrm{Ti} /\left(\mathrm{SnO}_{2}+\mathrm{Sb}_{2} \mathrm{O}_{3}\right)$ electrode and glass conductive electrode in aqueous solution at $298 \mathrm{~K}$.

\begin{tabular}{lcc}
\hline \multirow{2}{*}{ Acid $(\mathrm{M})$} & \multicolumn{2}{c}{ End point of $\mathrm{CH}_{3} \mathrm{COOH}$} \\
& G.E* & S.E** \\
\hline 0.0100 & 21.2 & 21.3 \\
0.0075 & 17.5 & 17.5 \\
0.0050 & 9.5 & 9.6 \\
0.0025 & 5.84 & 5.86 \\
\hline
\end{tabular}

* Glass electrode, ${ }^{* *}$ studied electrode.

TABle 5: The specific conductance of the conductometric cell on calibration with standard $\mathrm{KCl}$ solutions at $273 \mathrm{~K}$.

\begin{tabular}{lcr}
\hline $\mathrm{A}(\mathrm{M}) \mathrm{KCl}$ & Specific conductance $\left(\mathrm{mScm}^{-1}\right)$ & at $273 \mathrm{~K}$ \\
& $\mathrm{G.E}^{*}$ & S.E** \\
\hline 0.001 & 0.148 & 0.142 \\
0.010 & 1.413 & 1.392 \\
0.100 & 12.88 & 12.75 \\
\hline
\end{tabular}

${ }^{*}$ Glass electrode, ${ }^{* *}$ studied electrode.

between the results obtained by the solid-state $\mathrm{pH}$ sensor and that of the conventional glass $\mathrm{pH}$ electrode.

3.2. The Use of $\mathrm{Ti} /\left(\mathrm{SnO}_{2}+\mathrm{Sb}_{2} \mathrm{O}_{3}\right)$ Electrode as an Indicator Electrode in Conductometric Acid-Base Titration in Aqueous Solution at $298 \mathrm{~K}$

3.2.1. Conductometric Acid-Base Titration. Figure 7 shows the relation between the conductance of the pair $\mathrm{Ti} /\left(\mathrm{SnO}_{2}\right.$ $+\mathrm{Sb}_{2} \mathrm{O}_{3}$ ) electrode with $0.1 \mathrm{M} \mathrm{NaOH}$ in the titration of different concentrations of acetic acid at $298 \mathrm{~K}$. The conductance of the acetic acid will be low on account of its poor dissociation:

$$
\begin{aligned}
\mathrm{CH}_{3} \mathrm{COOH}(\mathrm{aq}) & +\left[\mathrm{Na}^{+}(\mathrm{aq})+\mathrm{OH}^{-}(\mathrm{aq})\right] \\
& \longrightarrow \mathrm{CH}_{3} \mathrm{COOH}(\mathrm{aq})+\mathrm{Na}^{+}(\mathrm{aq})+\mathrm{H}_{2} \mathrm{O}(\mathrm{l}) .
\end{aligned}
$$

On plotting the conductance against the volume of the alkali added, the two lines obtained will be as shown in Figure 7 . The point of intersection gives the end point.

The values of the recovery percentage, $R \%$, for all above titrations are calculated from (4). The calculated values of $R \%$ are listed in Table 3. It is clear from these data that the $\mathrm{Ti} /\left(\mathrm{SnO}_{2}+\mathrm{Sb}_{2} \mathrm{O}_{3}\right)$ electrode can be used as an indicator electrode with the satisfactory recovery percentage not less than $90.24 \%$. These differences in the recovery percentage may be attributed to the impurities in the reagents. Table 4 represents the relation between the endpoints of $\mathrm{CH}_{3} \mathrm{COOH}$ for $\mathrm{Ti} /\left(\mathrm{SnO}_{2}+\mathrm{Sb}_{2} \mathrm{O}_{3}\right)$ and glass conductive electrode at $298 \mathrm{~K}$.

Table 5 shows the values of constant of the conductometric cell obtained on the basis of the calibration with a standard solution of $\mathrm{KCl}$ and comparison with glass conductometric electrode.

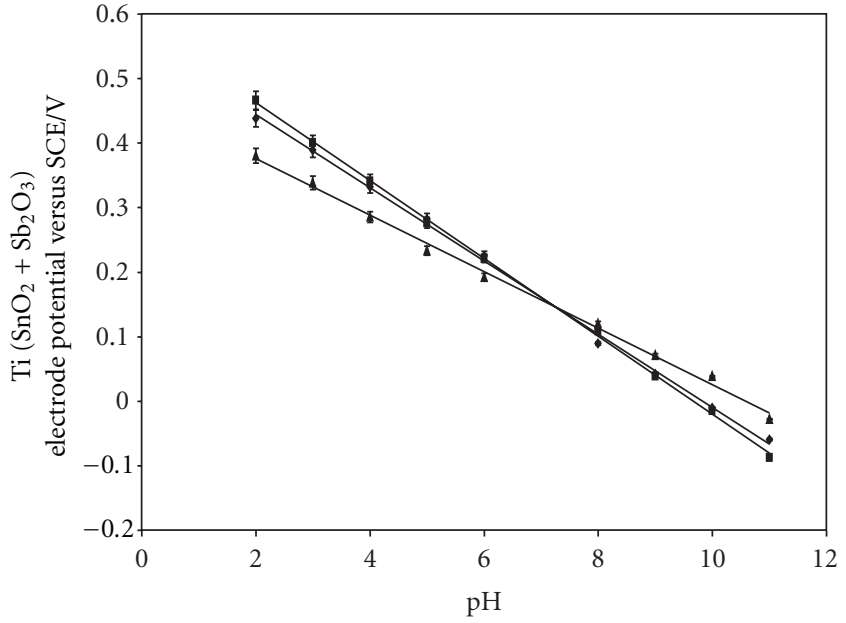

A $y=-0.0437 x+0.4628$
$y=-0.0568 x+0.558$
. $y=-0.0604 x+0.5835$

Figure 5: Effect of temperature on slope of Ti/ $\left(\mathrm{SnO}_{2}+\mathrm{Sb}_{2} \mathrm{O}_{3}\right) \mathrm{pH}$ sensor at $283 \mathrm{~K}(\boldsymbol{\Delta}), 333 \mathrm{~K}(\boldsymbol{\bullet})$ and $353 \mathrm{~K}(\boldsymbol{\square})$.

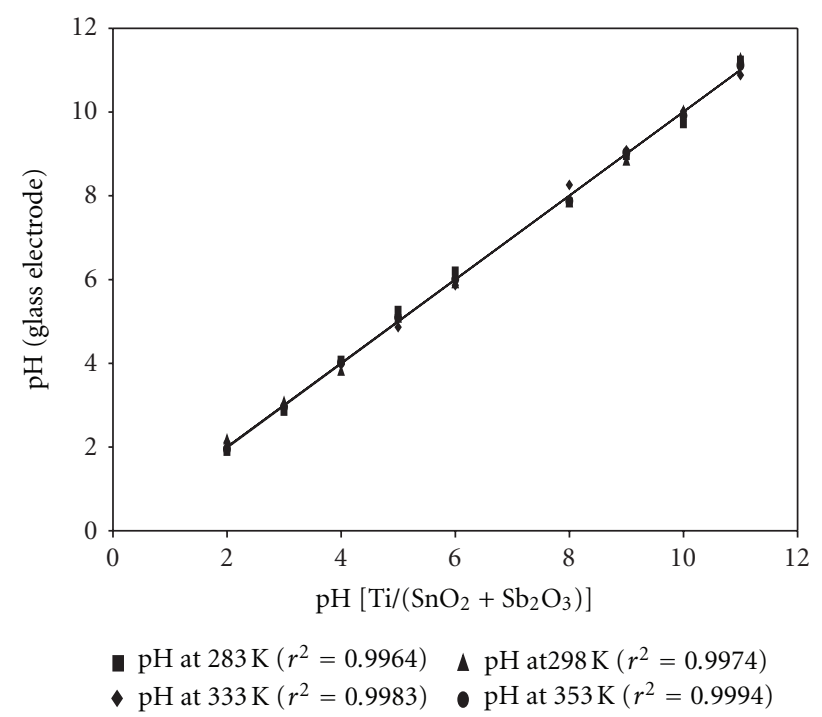

Figure 6: Correlation between the conventional glass $\mathrm{pH}$ electrode and $\mathrm{Ti} /\left(\mathrm{SnO}_{2}+\mathrm{Sb}_{2} \mathrm{O}_{3}\right) \mathrm{pH}$ sensor.

3.2.2. Cell Constant. The conductance obtained will, therefore, have to be multiplied by a certain factor in order to get the specific conductance. This factor is called the cell constant which is determined from the dimensions of the cell.

The value of cell constant for $\mathrm{Ti} /\left(\mathrm{SnO}_{2}+\mathrm{Sb}_{2} \mathrm{O}_{3}\right)$ electrodes in aqueous solutions at $298 \mathrm{~K}$ equals $148.4 \mathrm{~m}^{-1}$. Specific conductance of normal, decinormal, and centinormal solutions of potassium chloride at different temperatures is given in Table 6 . 
TABLE 6: The relation between the specific conductance of $\mathrm{KCl}$ solutions for $\mathrm{Ti} /\left(\mathrm{SnO} \mathrm{O}_{2}+\mathrm{Sb}_{2} \mathrm{O}_{3}\right)$ electrode against the glass conductive electrode at $273 \mathrm{~K}, 291 \mathrm{~K}$, and $298 \mathrm{~K}$.

\begin{tabular}{|c|c|c|c|c|c|c|}
\hline \multirow{2}{*}{$\mathrm{A}(\mathrm{M})$} & \multicolumn{2}{|c|}{ Specific conductance $\left(\mathrm{Sm}^{-1}\right)$ at $273 \mathrm{~K}$} & \multicolumn{2}{|c|}{ Specific conductance $\left(\mathrm{Sm}^{-1}\right)$ at $291 \mathrm{~K}$} & \multicolumn{2}{|c|}{ Specific conductance $\left(\mathrm{Sm}^{-1}\right)$ at $298 \mathrm{~K}$} \\
\hline & G.E* & S.E $E^{* *}$ & G.E* & S.E $E^{* *}$ & G.E* & S.E $E^{* *}$ \\
\hline 1.00 & 6.531 & 6.528 & 9.815 & 9.793 & 11.169 & 11.167 \\
\hline 0.10 & 0.715 & 0.714 & 1.119 & 1.119 & 1.288 & 1.288 \\
\hline 0.01 & 0.077 & 0.077 & 0.122 & 0.122 & 0.141 & 0.141 \\
\hline
\end{tabular}

${ }^{*}$ Glass electrode, ${ }^{* *}$ studied electrode.

TABLE 7: The relation between the molar conductance, $\Lambda_{m}$, in units of $10^{-4} \mathrm{Sm}^{2} \mathrm{~mol}^{-1}$, of some common electrolytes and the glass conductive electrode in aqueous solution at $298 \mathrm{~K}$.

\begin{tabular}{lcccccccccccc}
\hline \multirow{2}{*}{$\mathrm{A}(\mathrm{M})$} & \multicolumn{2}{c}{$\mathrm{HCl}$} & \multicolumn{2}{c}{$\mathrm{NaCl}$} & \multicolumn{2}{c}{$\mathrm{KCl}$} & \multicolumn{2}{c}{$\mathrm{H}_{2} \mathrm{SO}_{4}$} & \multicolumn{2}{c}{$\mathrm{CH}_{3} \mathrm{COOH}^{2} \mathrm{NH}_{4} \mathrm{OH}^{2}$} \\
& G.E* & S.E** & G.E* & S.E** & G.E* & S.E** & G.E* & S.E** & G.E* & S.E** & G.E* & S.E** \\
\hline 0.1000 & 391.5 & 392.04 & 107.01 & 107.13 & 128.84 & 128.79 & 249.78 & 249.72 & 5.18 & 5.15 & 3.6 & 3.61 \\
0.0100 & 412.3 & 411.92 & 118.51 & 118.47 & 141.13 & 140.09 & 336.35 & 336.28 & 16.09 & 15.78 & 16.29 & 16.287 \\
0.0010 & 421.4 & 420.98 & 123.7 & 123.67 & 146.9 & 147.005 & 399.5 & 399.44 & 48.18 & 48.11 & 49.201 & 49.217 \\
$0.0005 \mathrm{M}$ & 422.2 & 423.001 & 124.42 & 123.7 & 147.9 & 147.97 & 412.95 & 412.82 & 67.54 & 67.5 & 67.68 & 67.678 \\
\hline
\end{tabular}

${ }^{*}$ Glass electrode, ${ }^{* *}$ studied electrode.

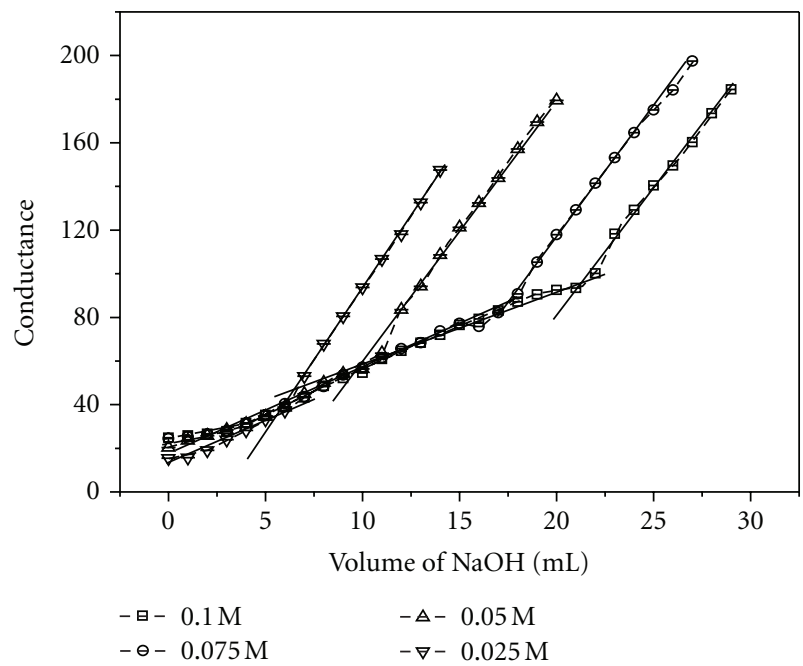

FIGURE 7: The relation between the conductance of a pair $\mathrm{Ti} /\left(\mathrm{SnO}_{2}\right.$ $+\mathrm{Sb}_{2} \mathrm{O}_{3}$ ) electrode in the titration of different concentration of $\mathrm{CH}_{3} \mathrm{COOH}$ with $0.1 \mathrm{M} \mathrm{NaOH}$ at $298 \mathrm{~K}$.

3.2.3. Variation of Molar Conductance with Dilution. Molar conductance of an electrolyte increases with the increase in dilution. This was attributed to an increase in the degree of dissociation of the electrolyte. We define the degree of dissociation as the fraction of the total electrolyte in solution which exists in the form of its ion. In other words, on dilution, the same amount of electrolyte is capable of furnishing a large number of ions. It may be pointed out, however, that the increase in the number of ions by dilution is much less than the increases in the volume of the solution. Therefore, the number of ions per unit volume (e.g., per c.c.) actually decreases. Hence, the specific conductance decreases although the molar conductance increases on progressive

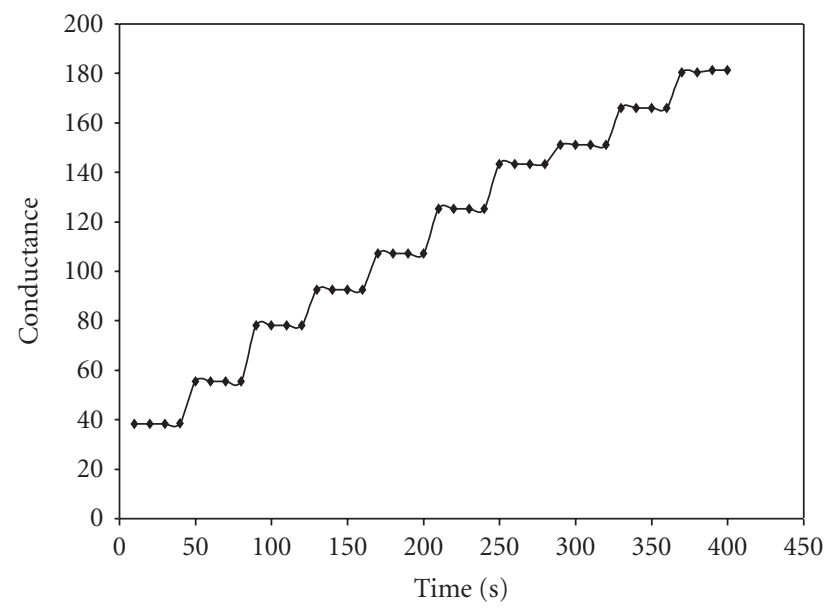

Figure 8: Time response curve of $\mathrm{Ti} /\left(\mathrm{SnO}_{2}+\mathrm{Sb}_{2} \mathrm{O}_{3}\right)$ electrode potential at different concentrations of acid. Upper curve at $0.1 \mathrm{M}$ and lower at $0.1 \mathrm{M}$.

dilution. It is seen that in each case molar conductance increases with dilution.

The variation of molar conductance with dilution for some common electrolytes is shown in Table 7 and the variation of molar conductance of infinite dilution in the case of some common electrolytes is shown in Table 8.

3.2.4. The Response Time of the Sensor. Figure 8 shows the time response curve as the continuous dependence of the conductance on time for several step changes of concentrations of acetic acid at $298 \mathrm{~K}$. It is clear that the response time for the studied conductometric cell is nearly 70 second, which rendered the sensor highly practical. 
TABle 8: The relation between the molar conductance, $\Lambda_{m}^{0}$, in units of $10^{-4} \mathrm{Sm}^{2} \mathrm{~mol}^{-1}$, at infinite dilution for some common electrolytes and that of glass conductive electrode in aqueous solution at $298 \mathrm{~K}$.

\begin{tabular}{lcc}
\hline Electrolyte & \multicolumn{1}{c}{$\Lambda_{m}^{0}\left(10^{-4} \mathrm{Sm}^{2} \mathrm{~mol}^{-1}\right)$} & \\
\hline $\mathrm{GCl}$ & 426.30 & S.E** \\
$\mathrm{NaCl}$ & 126.23 & 426.40 \\
$\mathrm{KCl}$ & 149.90 & 126.15 \\
$\mathrm{CH}_{3} \mathrm{COOH}$ & 390.51 & 148.83 \\
\hline
\end{tabular}

${ }^{*}$ Glass electrode, ${ }^{* *}$ studied electrode.

\section{Conclusion}

The recovery percentage for potentiometric and conductometric acid-base titration using $\mathrm{Ti} /\left(\mathrm{SnO}_{2}+\mathrm{Sb}_{2} \mathrm{O}_{3}\right)$ as indicator electrode was calculated. The $E-\mathrm{pH}$ curve is linear with slope of $0.0515 \mathrm{~V} /$ decade for the $\mathrm{Ti} /\left(\mathrm{SnO}_{2}+\mathrm{Sb}_{2} \mathrm{O}_{3}\right)$ electrode at $298 \mathrm{~K}$. This value is close to the theoretical value $2.303 \mathrm{RT} / \mathrm{F}(0.059 \mathrm{~V}$ at $298 \mathrm{~K})$. The standard potential of the tested electrode, $E^{0}$, is computed as $510 \mathrm{mV}$ with respect to SCE as reference electrode.

Acetic acid was successfully potentiometric and conductometric titrated with $\mathrm{NaOH}$ as titrant in aqueous medium at $298 \mathrm{~K}$. The cell constant for the pair electrode was determined from the dimensions of the cell. The relation between the specific conductance of standard $\mathrm{KCl}$ solutions for the cell against the glass conductive electrode at different temperatures was studied. The variation of molar conductance with dilution for some common electrolytes was tested using the modified electrode. Also the variation of molar conductance of infinite dilution in case of some common electrolytes is determined by each conductive cell and the conductive glass electrode.

\section{References}

[1] K. Peter, "Metal oxides and ion-exchanging surfaces as $\mathrm{pH}$ sensors in liquids: state-of-the-art and outlook," Sensors, vol. 9, no. 6, pp. 4955-4985, 2009.

[2] D. Himmel, S. K. Goll, I. Leito, and I. Krossing, "A unified pH scale for all phases," Angewandte Chemie International Edition, vol. 49, no. 38, pp. 6885-6888, 2010.

[3] P. Benezeth and D. A. Palmer, "Potentiometric determination of cadmium-acetate complexation in aqueous solutions to $250^{\circ}$ C," Chemical Geology, vol. 167, no. 1, pp. 11-24, 2000.

[4] M. F. S. Teixeira, L. A. Ramos, E. A. Neves, and E. T. G. Cavalheiro, "A solid $\mathrm{Fe}_{2} \mathrm{O}_{3}$ based carbon-epoxy electrode for potentiometric measurements of $\mathrm{pH}$," Portugaliae Electrochimica Acta, vol. 20, pp. 139-149, 2002.

[5] E. M. El-Giar and D. O. Wipf, "Microparticle-based iridium oxide ultramicroelectrodes for $\mathrm{pH}$ sensing and imaging," Journal of Electroanalytical Chemistry, vol. 609, no. 2, pp. 147154, 2007.

[6] M. F. Teixeira, F. C. Moraes, O. Fatibello-Filho, L. C. Ferracin, R. C. Rocha-Filho, and N. Bocchi, "Novel $\lambda-\mathrm{MnO}_{2}$-based graphite-epoxy electrode for potentiometric determination of acids and bases," Sensors and Actuators B, vol. 56, no. 1, pp. 169-174, 1999.

[7] G. G. Cross, T. M. Fyles, and V. V. Suresh, "Coatedwire electrodes containing polymer immobilized ionophores blended with poly(vinyl chloride)," Talanta, vol. 41, no. 9, pp. 1589-1596, 1994.

[8] Y. Ha and M. Wang, "Capillary melt method for micro antimony oxide pH electrode," Electroanalysis, vol. 18, no. 11, pp. 1121-1125, 2006.

[9] H. Razmi, H. Heidari, and E. Habibi, "Ph-sensing properties of $\mathrm{PbO}_{2}$ thin film electrodeposited on carbon ceramic electrode," Journal of Solid State Electrochemistry, vol. 12, no. 12, pp. 1579-1587, 2008.

[10] L. A. Pocrifka, C. Gonçalves, P. Grossi, P. C. Colpa, and E. C. Pereira, "Development of $\mathrm{RuO}_{2}-\mathrm{TiO}_{2}$ (70-30) mol\% for $\mathrm{pH}$ measurements," Sensors and Actuators B, vol. 113, no. 2, pp. 1012-1016, 2006.

[11] A. C. Lima, A. A. Jesus, M. A. Tenan, A. F. D. S. Silva, and A. F. Oliveira, "Evaluation of a high sensitivity $\mathrm{PbO}_{2} \mathrm{pH}$-sensor," Talanta, vol. 66, no. 1, pp. 225-228, 2005.

[12] S. A. M. Marzouk, "Improved electrodeposited iridium oxide pH sensor fabricated on etched titanium substrates," Analytical Chemistry, vol. 75, no. 6, pp. 1258-1266, 2003.

[13] I. A. Ges, B. L. Ivanov, A. A. Werdich, and F. J. Baudenbacher, "Differential pH measurements of metabolic cellular activity in $\mathrm{nl}$ culture volumes using microfabricated iridium oxide electrodes," Biosensors and Bioelectronics, vol. 22, no. 7, pp. 1303-1310, 2007.

[14] N. M. Abu Ghalwa, Journal of Al-Azhar University, Gaza, vol. 7, p. $55,2004$.

[15] N. Abu Ghalwa, Global Journal of Analytical Chemistry, vol. 3, p. 16, 2012.

[16] I. Pochard, A. Foissy, and P. Couchot, "Conductometric and microcalorimetric analysis of the alkaline-earth/alkali-metal ion exchange onto polyacrylic acid," Colloid and Polymer Science, vol. 277, no. 9, pp. 818-826, 1999.

[17] R. M. Kakhki, T. Heydari, and G. Rounaghi, "Artificial neural networks applied for simultaneous analysis of mixtures of nitrophenols by conductometric acid-base titration," Industrial \& Engineering Chemistry Research, vol. 50, no. 19, pp. 11375-11381, 2011.

[18] L. H. G. Coelho and I. G. R. Gutz, "Trace analysis of acids and bases by conductometric titration with multiparametric nonlinear regression," Talanta, vol. 69, no. 1, pp. 204-209, 2006.

[19] S. Pantel and H. Weisz, "Catalytic end-point detection in titrimetric analysis," Analytica Chimica Acta, vol. 202, pp. 124, 2002.

[20] R. Ghorbani, J. Ghasemi, and B. Abdollahi, "Conductometric simultaneous determination of acetic acid, monochloroacetic acid and trichloroacetic acid using orthogonal signal correction-partial least squares," Journal of Hazardous Materials, vol. 131, no. 1-3, pp. 13-18, 2006.

[21] F. Gaslini and L. Z. Nahum, "Conductometric titration of metal acetates in aqueous medium," Analytica Chimica Acta, vol. 24, pp. 79-82, 1961.

[22] J. Wu, J. Suls, and W. Sansen, "Electrical properties of polysilicon electrodes for conductometric measurement," Journal of Electroanalysis, vol. 12, no. 7, pp. 538-541, 2000.

[23] M. Novotny, F. Opekar, I. Jelinek, and K. Stulik, "Improved dual photometric-contactless conductometric detector for capillary electrophoresis," Analytica Chimica Acta, vol. 525, no. 1, pp. 17-21, 2004. 
[24] Z. Zhang, S. Xia, D. Leonard et al., "A novel nitrite biosensor based on conductometric electrode modified with cytochrome c nitrite reductase composite membrane," Biosensors and Bioelectronics, vol. 24, no. 6, pp. 1574-1579, 2009.

[25] Z. Zhang, N. Jaffrezic-Renault, F. Bessueille et al., "Development of a conductometric phosphate biosensor based on tri-layer maltose phosphorylase composite films," Analytica Chimica Acta, vol. 615, no. 1, pp. 73-79, 2008.

[26] B. Khadro, P. Namour, F. Bessueille, D. Leonard, and N. Jaffrezic-Renault, "A novel conductometric sensor based on a PVC membrane containing nonactin for ammonium determination," International Journal of Environmental Analytical Chemistry, vol. 89, no. 1, pp. 11-19, 2009.

[27] X. Yang, R. Zou, F. Huo, D. Cai, and D. Xiao, "Preparation and characterization of $\mathrm{Ti} / \mathrm{SnO}_{2}-\mathrm{Sb}_{2} \mathrm{O}_{3}-\mathrm{Nb}_{2} \mathrm{O}_{5} / \mathrm{PbO}_{2}$ thin film as electrode material for the degradation of phenol," Journal of Hazardous Materials, vol. 164, pp. 367-373, 2009.

[28] A. M. Polcaro, S. Palmas, F. Renoldi, and M. Mascia, "On the performance of $\mathrm{Ti} / \mathrm{SnO}_{2}$ and $\mathrm{Ti} / \mathrm{PbO}_{2}$ anodes in electrochemical degradation of 2-chlorophenol for wastewater treatment," Journal of Applied Electrochemistry, vol. 29, no. 2, pp. 147-151, 1999.

[29] L. Lipp and D. Pletcher, "The preparation and characterization of tin dioxide coated titanium electrodes," Electrochimica Acta, vol. 42, no. 7, pp. 1091-1099, 1997.

[30] J. A. Illingworth, "A common source of error in $\mathrm{pH}$ measurements," Biochemical Journal, vol. 195, no. 1, pp. 259-262, 1981.

[31] A. I. Vogel, Quantitative Inorganic Analysis, Longmans, England, UK, 3rd edition, 1961. 

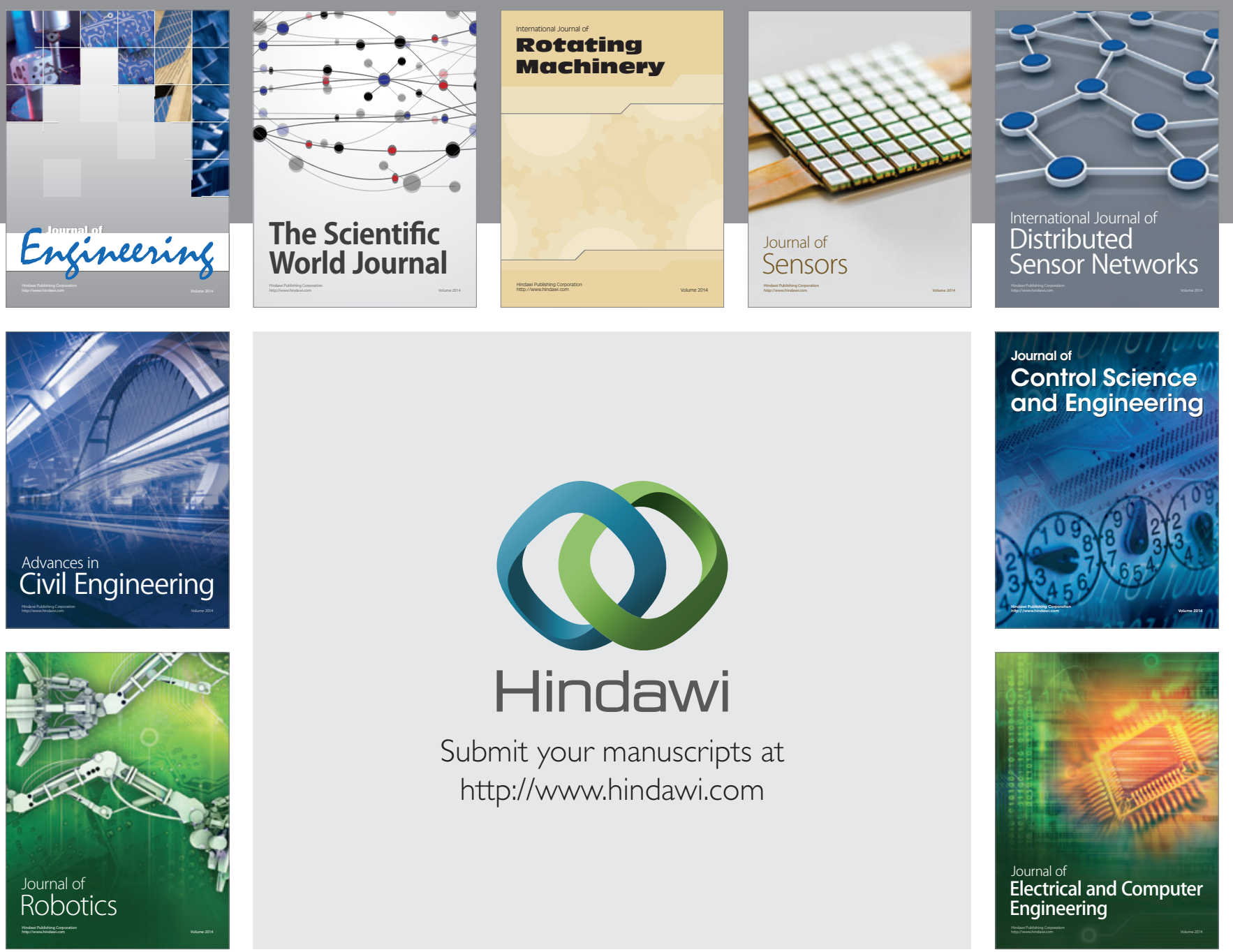

Submit your manuscripts at

http://www.hindawi.com
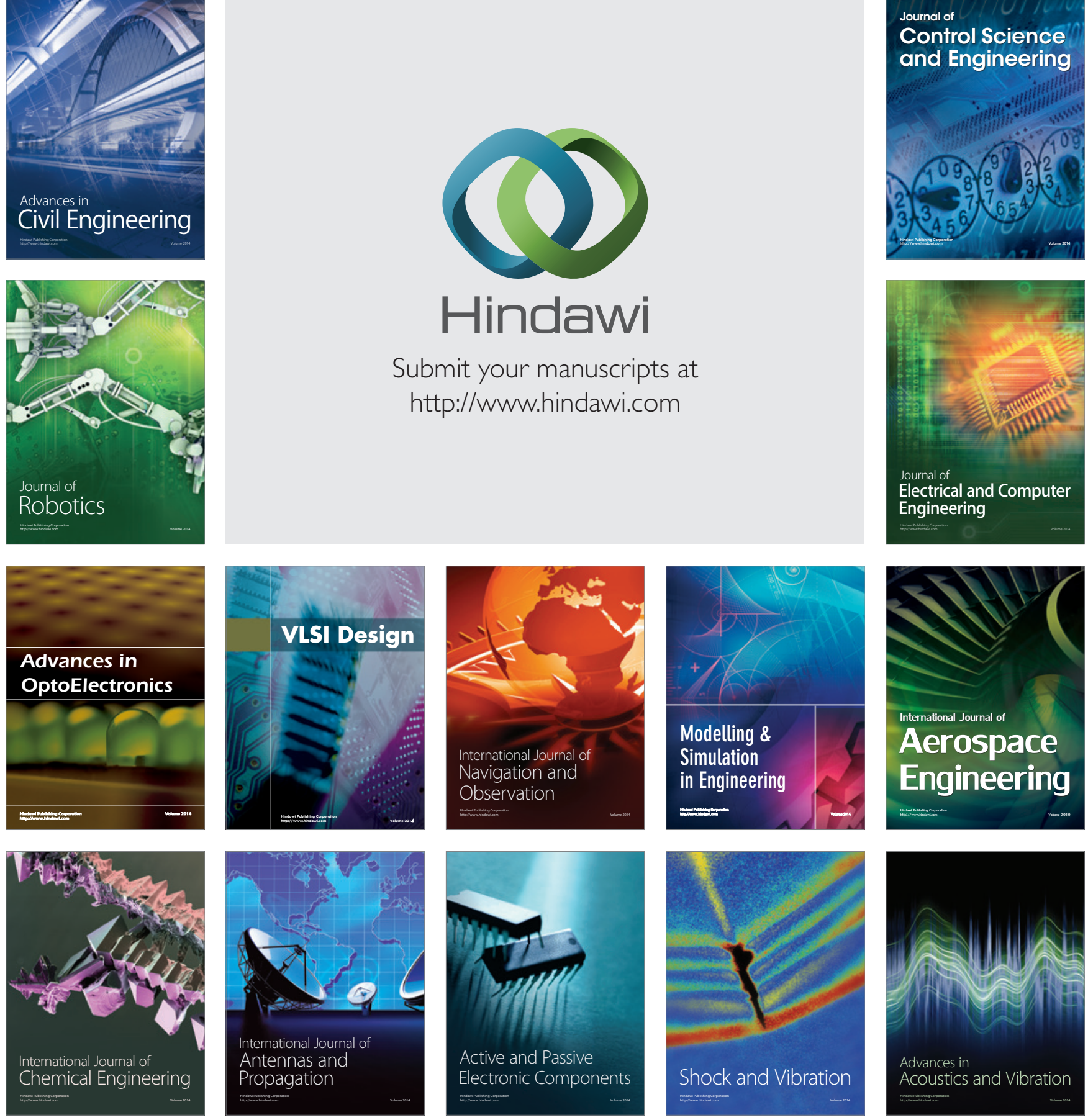